\title{
Dosimetric Comparison of Three-Dimensional Conformal Radiotherapy, Forward-Planned Intensity Modulated Radiotherapy and Volumetric Modulated Arc Therapy in Intact Breast Radiotherapy without Lymphatic Irradiation
}

\section{Lenfatik Işınlamanın Yapılmadığı İntakt Meme Radyoterapisinde 3DCRT, forward-planned IMRT ve VMAT'nin Dosimetric Karşılaştırması}

\author{
Zümrüt Ada Kaymak Çerkeşli ${ }^{1}$, Fevziye İlknur Kayalı², Rahşan Habiboğlu² \\ ${ }^{1}$ Süleyman Demirel University, Radiation Oncology Department, Isparta, Turkey \\ ${ }^{2}$ Ankara Numune Training And Education Hospital Radiation Oncology Clinic, Ankara, Turkey
}

Dergiye Ulaşma Tarihi: 21.05.2019 Dergiye Kabul Tarihi: 19.07.2019 Doi: 10.5505/aot.2019.06977

\section{ÖZET}

GİRIŞ ve AMAÇ: Bu çalışmada; meme kanseri vakalarının çoğunluğunu oluşturan, lenf nodu tutulumu olmayan hastalarda, meme koruyucu cerrahi sonrası tüm meme radyoterapisi için en uygun tekniğin araştırılması amaçlanmıştır. Yaygın kullanılan üç boyutlu konformal radyoterapi (3DKRT), uygun maliyetli kabul edilen statik Yoğunluk Ayarlı Radyoterapi (sYART) ve yeni kullanıma giren Volümetrik Ayarlı Ark Terapi (VMAT) dozimetrik olarak karşılaştırıldı.

YÖNTEM ve GEREÇLER: Çalışmada sIMRT ile tedavi almış 16 sağ ve 19 sol meme kanseri tanılı hastanın bilgisayarlı tomografi(BT) simülasyon kesitleri kullanıldı. Tüm planlamalar Eclipse 10,0 sistemi ile yapıldı. Uygulanan doz total 50Gy/25fraksiyonda, konvansiyonel şema olarak belirlendi. Teknikler hedef volüm ve kritik organ (ipsilateral akciğer, kalp, kontrlateral meme ve kontrlateral akciğer) dozları açısından karşılaştırıldı. BULGULAR: Üç teknik de Hedef Sarımı(TC) başarıyla sağlamıştır. sYART, 3DKRT'e göre Planlanan Hedef Volüm (PTV) maksimum dozunu (Dmax) düşürmektedir. En iyi PTV doz homojenitesi VMAT ile sağlanmıştır. sYART tüm kritik organ dozlarında 3DKRT'ye göre düşüş sağlamaktadır ve bu düşüş ipsilateral akciğer ortalama dozu(Dmean), Dmax, 40Gy ve üstü doz alan volüm(V40); kontrlateral meme Dmax ve V5 için istatistiksel olarak anlamlı bulunmuştur. VMAT diğer iki yönteme göre ipsilateral akciğer Dmax, V20, V30, V40 ve sol meme kanseri hastalarında kalp Dmax ve V35'i düşürmüştür; fakat ipsilateral akciğer Dmean, V5, V10; kontrlateral akciğer ve meme Dmean, Dmax, V5; sağ meme ca hastalarında kalp Dmax, Dmean, V5, V10; sol meme kanseri hastalarında kalp Dmean, V5, V10'u anlamlı yükseltmiştir.

TARTIŞMA ve SONUÇ: İntakt meme radyoterapisi için 3DKRT yerine sYART daha iyi dozimetri sağlamaktadır, bu sebeple mümkün oldukça tercih edilmelidir. VMAT ile daha homojen doz dağılımları sağlanır. Ayrıca VMAT ile ipsilateral kritik organ yüksek dozları düşerken, ipsilateral ve kontrlateral kritik organ düşük dozları anlamlı artış göstermektedir. Bu durumun sonuçları uzun takipli klinik çalışmalar ile incelenmelidir.

Anahtar Kelimeler: Radyoterapi, meme kanseri, 3 boyutlu konformal radyoterapi, forward-planned IMRT, VMAT

\begin{abstract}
INTRODUCTION: The present study aimed to determine the most suitable technique for whole breast radiotherapy after breast conserving surgery in patients without lymph node involvement; those that constitute the majority of breast cancer cases. Three-dimensional conformal radiotherapy (3DCRT), that is widely used, forward planned intensity-modulated radiotherapy (forIMRT), that is accepted to be cost-effective, and volumetric modulated arc therapy (VMAT), that has become available recently, were dosimetrically compared. METHODS: Computed tomography simulation cross-sections of 16 patients with right breast cancer and 19 patients with left breast cancer, who had been treated with forIMRT, were used in the study. All planning was done using Eclipse 10.0 treatment planning system. A conventional scheme consisting of a total dose of 50Gy
\end{abstract}


given in 25 fractions was used. The techniques were compared in terms of target volume and critical organ (ipsilateral lung, heart, contralateral breast and contralateral lung) doses.

RESULTS: We successfully achieved target coverage (TC) by all three techniques. Forward IMRT led to a higher decrease in planned target volume (PTV) maximum dose (Dmax), in comparison to 3DCRT. The best PTV dose homogeneity was achieved with VMAT. forIMRT resulted in higher reductions in all critical organ doses when compared to 3DCRT, and the decrease was significantly higher in the ipsilateral lung mean dose (Dmean) and Dmax and the volume of ipsilateral lung receiving $\geq 40 \mathrm{~Gy}$ (V40), and contralateral breast Dmax and V5. Compared to the other two methods, VMAT led to a greater decrease in Dmax, V20, V30 and V40 of the ipsilateral lung and Dmax and V35 of the heart in left breast cancer patients; but led to a significant increase in Dmean, V5 and V10 of the ipsilateral lung; Dmean, Dmax, and V5 of the contralateral lung and breast, and Dmax, Dmean, V5 and V10 of the heart in right breast cancer patients; and Dmean, V5, and V10 of the heart in left breast cancer patients.

DISCUSSION AND CONCLUSION: forIMRT provides a better dosimetry than 3DCRT for intact breast radiotherapy; therefore, it should be preferred, whenever possible. More homogeneous dose distributions are achieved with VMAT. Additionally, while ipsilateral critical organ high doses decrease by VMAT, ipsilateral and contralateral critical organ low doses show a significant increase. The outcomes of this condition should be studied in clinical studies with long-term follow-up.

Keywords: radiotherapy, breast cancer, 3 dimentional conformal radiotherapy, forward-planned IMRT, VMAT

\section{INTRODUCTION}

Lymph nodes are not involved in $61 \%$ of breast cancer patients at the time of diagnosis and 5 year survival rates of these patients is $98.5 \%$ according to the National Cancer Institute's (NCI) Surveillance, Epidemiology, and End Results (SEER) 2003-2009 report (1). The standard approach in this "localized disease group" that constitutes the majority of breast cancer cases, is whole breast radiotherapy after breast conserving surgery. Long-term survival duration increase the importance of the quality of radiotherapy techniques applied to these patients.

Three-dimensional conformal radiotherapy (3DCRT) planning is commonly used with curative intent in breast cancer patients. Tangential fields to the breast/chest wall are used in 3DCRT planning. By the introduction of intensity-modulated radiotherapy (IMRT), a more homogeneous dose distribution in target volume and a decrease in critical organ doses were provided in RT planning of breast cancer patients (2-4). Forward planned IMRT (forIMRT) technique, applied by adding only a few additional fields to the tangential fields used in three-dimensional planning, provides a better homogeneity compared to 3DCRT and a similar homogeneity to inverse planned IMRT (5-7).

Cardiac mortality may be increased by breast cancer radiotherapy(RT), especially in left breast cancer patients who receive radiotherapy to regional lymphatics and internal mammary lymph nodes (8-10). Dosimetric studies comparing IMRT, helical tomotherapy and volumetric modulated arc therapy (VMAT) in left breast cancer patients, who require nodal irradiation to decrease heart doses, have been performed. Both a more homogeneous dose distribution and a decrease in critical organ high doses can be provided with VMAT or helical tomotherapy. Furthermore, duration of treatment is shortened $(3,11)$. Scorsetti et al. (12) reported the preliminary results of patients treated with VMAT for breast radiotherapy in 2012.

In the present study; 3DCRT, which is commonly used in early stage breast cancer without lymphatic irradiation, forIMRT that is considered to be cost-effective and VMAT, which is newly introduced into practice were aimed to be dosimetrically compared in conventional fraction scheme in terms of target volume and critical organ doses.

\section{MATERIALS and METHOD}

In the study, CT simulation cross-sections of 35 patients who had been treated with forIMRT technique, using Varian Trilogy Linear Accelerator in Ankara Numune Research and Education Hospital Radiation Oncology Clinic between October 2011 and September 2012, were used. 3DCRT and VMAT planning were performed on the delinated targets that were already exist for forIMRT planning. Eclipse 10.0 treatment planning system was used for all contouring and dosimetric calculations.

All patients, who had been admitted to our clinic within the time specified, who had no pathologic lymph node involvement and had undergone breast conserving surgery, were 
included in the study. The patients were simulated in supine position by GE computed Tomography. A total dose of 50 Gy was delivered in 25 fractions for whole breast radiotherapy in all patients. Additionally, a boost dose of (electron or photon) 10 to 16Gy was delivered to the tumor bed of the patients.

Breast Cancer Atlas for radiation therapy published by the Radiation Oncology Group (RTOG) was used in contouring. Ipsilateral lung, heart, contralateral lung, contralateral breast, esophagus and spinal cord (SC) were contoured as critical organs. As the estimated dose for SC and esophagus was close to 0Gy, they were not considered in the assessments.

\section{Treatment planning}

Two opposing tangential fields were created using $6 \mathrm{MV} \mathrm{X}$-rays in 3DCRT planning. Multileaf collimators (MLC) were used to shield the heart or lung, where required. In necessary conditions, wedges were used for dose homogenization.

Tangential fields with the same energy level used in 3DCRT were used in forIMRT planning. After two open tangential fields had been created, additional fields (field-in-field) were formed until hot spots are maintained below $107 \%$ of the prescribed dose.

In VMAT, the gantry moves continuously around the patient in single or multiple arcs. Dose rate is variable and multileaf collimators are in continuous movement. During VMAT planning, VMAT planning strategies published by the Medical Physics Unit of the Oncology Institute of Southern Switzerland was taken into consideration, and two coplanar arcs were used (13).

\section{Dosimetric comparison}

All RT planning was done in the way that $95 \%$ of the Planned Target Volume (PTV) would receive $\geq 95 \%$ of the prescribed dose (D95 $\geq$ $95 \%$ ). In order to provide homogeneity in forIMRT and VMAT planning, hot spots were tried to be maintained below $107 \%$ of the prescribed dose. For 3DCRT, hot spots were maintained at maximum $110-115 \%$.

Minimum (Dmin), maximum $(\mathrm{D} \max =\mathrm{D} 2 \%$ : maximum dose received by at least $2 \%$ of the volume) and mean doses (Dmean) for PTV and target coverage (TC) were calculated for all three planning. TC was defined as the planned target volume receiving $\geq 95 \%$ of the planned dose.
Homogeneity index (HI) was used to compare the homogeneity of the techniques. PTV volume receiving $95 \%$ to $105 \%$ of the dose was defined as HI.

Heart, ipsilateral lung, contralateral breast and contralateral lung were assessed as the critical organs. In the comparison of the three techniques; ipsilateral lung Dmax, Dmean and percentage of the organ volume that receives $\geq 5 \mathrm{~Gy}$ (V5), V10, V20, V30 and V40 were assessed. Heart Dmax, Dmean and V5, V10 and V35 were calculated. In the assessment of heart doses, the data of patients diagnosed with right and left breast cancer were compared separately. Doses received by contralateral lung and contralateral breast were evaluated by Dmax, Dmean and V5. Parameters were obtained from dose volume histograms (DVH) of each patient and the mean/median values of each parameter were calculated for all patients. A patient was diagnosed to have bilateral breast cancer and a contralateral mastectomy was performed so contralateral breast doses were assessed over the results of 34 patients.

Repeated measures analysis of variance was used to find the difference between the mean/median values of the parameters with normal distribution; in case of non-normal distribution, significance of the difference was analyzed using the Friedman test. P value $<0.05$ was considered statistically significant.

\section{RESULTS}

CT simulation cross-sections of a total of 35 breast cancer patients, 16 patients with right breast cancer, and 19 patients with left breast cancer were used in our study.

\section{Comparison of Target Volume Doses}

The mean PTV of 35 patients was $1039.3 \mathrm{~cm}^{3}$ (349-1724).

In the comparison of 3DCRT, forIMRT and VMAT planning in terms of PTV Dmax, it was found that mean Dmax (54Gy) in 3DCRT was significantly higher than that in forIMRT (52.9Gy) and in VMAT (53.2Gy) ( $<<0.05)$.

Each of the three planning techniques provided a successful TC and there was no difference between them $(95.6 \%$ for 3DCRT $95.6 \%$ for forIMRT and $95.3 \%$ for VMAT). The mean homogeneity index was calculated as $76.4 \%$ for 3DCRT, $85.1 \%$ for forIMRT and $88.6 \%$ for VMAT. While VMAT provided the best homogeneity, forIMRT provided a better 
homogeneity than 3DCRT. PTV dose distribution parameters of the patients can be viewed from Table 1. Figure 1 and Figure 2 demonstrate the axial view of dose distribution of two sample cases.

\begin{tabular}{|c|c|c|c|c|c|}
\hline Parameter & $3 D C R T$ & forIMRT & VMAT & & $p$ \\
\hline Dmean (Gy) & $50,7 \pm 0,7$ & $50,5 \pm 0,6$ & $50,7 \pm 0,4$ & No difference & 0,12 \\
\hline $\operatorname{Dmin}(G y)$ & $35,7(11,2-41,9)$ & $35,1(10,7-42,5)$ & $37,4(21,7-42,5)$ & No difference & 0,28 \\
\hline $\operatorname{Dmax}(G y)$ & $54(51,5-56,1)$ & $52,9(51,2-54,7)$ & $53,2(51,2-54,4)$ & $\begin{array}{l}\text { 3DCRT-forIMRT 3DCRT-VMAT } \\
\text { forIMRT-VMAT }\end{array}$ & $\begin{array}{l}<\mathbf{0 , 0 5} \\
<\mathbf{0 , 0 5} \\
>0,05\end{array}$ \\
\hline$T C(\%)$ & $95,6(95-98,7)$ & $95,6(95-97,9)$ & $95,3(95-96,2)$ & No difference & 0,102 \\
\hline$H I(\%)$ & $76,4(32,9-95,7)$ & $85,1(55-98)$ & $88,6(71,5-95,2)$ & $\begin{array}{l}\text { 3DCRT-forIMRT } \\
\text { 3DCRT-VMAT } \\
\text { forIMRT-VMAT }\end{array}$ & $\begin{array}{l}<0,05 \\
<0,05 \\
<0,05\end{array}$ \\
\hline
\end{tabular}

Data are presented as mean \pm standard deviation or median (minimum-maximum), where appropriate.

Abreviations: 3DCRT=Three-dimensional conformal radiotherapy; forIMRT = Forward planned intensity-modulated radiotherapy; VMAT $=$ Volumetric modulated arc therapy; Dmean= Mean dose Dmin=Minimum dose; Dmax=Maximum dose; $\mathrm{TC}=$ Target coverage; $\mathrm{HI}=$ Homogeneity index

\section{Comparison of normal tissue doses}

Comparison of critical organ parameters is given in Table 2 and 3.

The highest ipsilateral lung Dmean was achieved by VMAT (11.6Gy), followed by 3DCRT (9.4Gy) and forIMRT (9.2Gy) $(\mathrm{p}<0.001)$. It was observed that, in comparison to 3DCRT, forIMRT and VMAT provided a statistically significant decrease in ipsilateral lung Dmax. While V5 of ipsilateral lung was $74.5 \%$ by VMAT, it was $25.2 \%$ and $24.8 \%$ by
3DCRT and forIMRT, respectively. Ipsilateral lung V20 and V30 were statistically significantly lower by VMAT in comparison to 3DCRT and forIMRT $(\mathrm{p}<0.05)$. The decrease in dose achieved by VMAT became significant after V20 and the most significant decrease was observed at V40 value. Better V5, V10, V20, $\mathrm{V} 30$ and $\mathrm{V} 40$ results were obtained by forIMRT in comparison to 3DCRT, but statistical significance was determined only for V40.

\begin{tabular}{|c|c|c|c|c|c|}
\hline Parameter & $3 D C R T$ & forIMRT & VMAT & & $p$ \\
\hline \multicolumn{6}{|l|}{ Ipsilateral Lung } \\
\hline \multirow[t]{3}{*}{ Dmean $(G y)$} & $9,4 \pm 2,6$ & $9,2 \pm 2,39$ & $11,6 \pm 1,9$ & 3DCRT-forIMRT & $<0,05$ \\
\hline & & & & 3DCRT-VMAT & $=0,001$ \\
\hline & & & & forIMRT-VMAT & $<0,001$ \\
\hline \multirow[t]{3}{*}{$\operatorname{Dmax}(G y)$} & $51,8 \pm 1,5$ & $50,8 \pm 1,1$ & $49,9 \pm 2,3$ & 3DCRT -forIMRT & $<0,001$ \\
\hline & & & & 3DCRT- VMAT & $<0,001$ \\
\hline & & & & forIMRT-VMAT & $=0,09$ \\
\hline \multirow[t]{3}{*}{$V 5(\%)$} & $25,2(12-46)$ & $24,8(13,6-43)$ & $74,5(15,8-48,9)$ & 3DCRT-forIMRT & $>0,05$ \\
\hline & & & & 3DCRT -VMAT & $<0,001$ \\
\hline & & & & forIMRT -VMAT & $<0,001$ \\
\hline \multirow[t]{3}{*}{$V 10(\%)$} & $20,5(10-41,5)$ & $20,4(10,2-38,9)$ & $40,9(26,3-64,3)$ & 3DCRT-forIMRT & $>0,05$ \\
\hline & & & & 3DCRT -VMAT & $<0,001$ \\
\hline & & & & forIMRT - VMAT & $<0,001$ \\
\hline \multirow{3}{*}{$V 20(\%)$} & $17,5 \pm 5,5$ & $17,3 \pm 5,1$ & $16 \pm 4,1$ & 3DCRT-forIMRT & $>0,05$ \\
\hline & & & & 3DCRT -VMAT & $<0,001$ \\
\hline & & & & forIMRT -VMAT & $<0,001$ \\
\hline \multirow[t]{3}{*}{ V30(\%) } & $15,2 \pm 4,8$ & $15 \pm 4,5$ & $7,2 \pm 3,2$ & 3DCRT-forIMRT & $=0,302$ \\
\hline & & & & 3DCRT - VMAT & $<0,001$ \\
\hline & & & & forIMRT -VMAT & $<0,001$ \\
\hline \multirow[t]{2}{*}{$V 40(\%)$} & $13 \pm 4,5$ & $12,5 \pm 4,2$ & $1,8 \pm 1,7$ & 3DCRT -forIMRT & $<0,05$ \\
\hline & & & & 3DCRT - VMAT & $<0,001$ \\
\hline
\end{tabular}




\begin{tabular}{|c|c|c|c|c|c|}
\hline & & & & forIMRT - VMAT & $<0,001$ \\
\hline \multicolumn{6}{|l|}{ Contrlateral Lung } \\
\hline \multirow[t]{3}{*}{$\operatorname{Dmean}(G y)$} & $0,4(0,3-0,7)$ & $0,4(0,3-0,6)$ & $3,7(1,2-6,7)$ & 3DCRT-forIMRT & $>0,05$ \\
\hline & & & & 3DCRT-VMAT & $<0,001$ \\
\hline & & & & forIMRT-VMAT & $<0,001$ \\
\hline \multirow[t]{3}{*}{$\operatorname{Dmax}(G y)$} & $2,6(1,3-6,2)$ & $2,5(1,3-6)$ & $16,2(7,5-27,3)$ & 3DCRT-forIMRT & $>0,05$ \\
\hline & & & & 3DCRT-VMAT & $<0,001$ \\
\hline & & & & forIMRT-VMAT & $<0,001$ \\
\hline \multirow[t]{2}{*}{$V 5(\%)$} & 0 & 0 & $22(1,1-70,3)$ & 3DCRT-VMAT & $<0,001$ \\
\hline & & & & forIMRT-VMAT & $<0,001$ \\
\hline \multicolumn{6}{|c|}{ Contrlateral Breast } \\
\hline \multirow[t]{3}{*}{$\operatorname{Dmean}(G y)$} & $0,7(0,2-3,3)$ & $0,6(0,2-2,5)$ & $5,2(2,2-51,3)$ & 3DCRT-forIMRT & $>0,05$ \\
\hline & & & & 3DCRT-VMAT & $<0,001$ \\
\hline & & & & forIMRT-VMAT & $<0,001$ \\
\hline \multirow[t]{3}{*}{$\operatorname{Dmax}(G y)$} & $19,3(11,3-55,3)$ & $17,7(1,3-50)$ & $19,7(10,1-41,2)$ & 3DCRT - forIMRT & $<0,05$ \\
\hline & & & & 3DCRT -VMAT & $<0,05$ \\
\hline & & & & forIMRT - VMAT & $<0,05$ \\
\hline \multirow[t]{3}{*}{$V 5(\%)$} & $0,7(0-13,1)$ & $0,6(0-9,5)$ & $23,4(7,8-44,6)$ & 3DCRT - forIMRT & $<0,05$ \\
\hline & & & & 3DCRT -VMAT & $<0,001$ \\
\hline & & & & forIMRT - VMAT & $<0,001$ \\
\hline
\end{tabular}

Data are presented as mean \pm standard deviation or median (minimum-maximum), where appropriate. Abbreviations: 3 DCRT=Three-dimensional conformal radiotherapy; forIMRT=Forward planned intensity-modulated radiotherapy; VMAT=Volumetric modulated arc therapy; Dmean=Mean dose; Dmin=Minimum dose; Dmax=Maximum dose

\begin{tabular}{|c|c|c|c|c|c|}
\hline Parameter & $3 D C R T$ & ForIMRT & VMAT & & $p$ \\
\hline \multicolumn{6}{|c|}{ Heart parameters of right breast cancer patients } \\
\hline Dmean $(G y)$ & $1,2 \pm 0,2$ & $1,1 \pm 0,1$ & $5,8 \pm 1,8$ & $\begin{array}{l}\text { 3DCRT- IMRT } \\
\text { 3DCRT -VMAT } \\
\text { forIMRT -VMAT }\end{array}$ & $\begin{array}{l}=0,216 \\
<\mathbf{0 , 0 0 1} \\
<\mathbf{0 , 0 0 1}\end{array}$ \\
\hline $\operatorname{Dmax}(G y)$ & $6,9(2,6-21)$ & $6,5(2,6-21,7)$ & $17,3(9,4-25,3)$ & $\begin{array}{l}\text { 3DCRT- IMRT } \\
\text { 3DCRT -VMAT } \\
\text { forIMRT - VMAT }\end{array}$ & $\begin{array}{l}>0,05 \\
<\mathbf{0 , 0 0 1} \\
<\mathbf{0 , 0 0 1}\end{array}$ \\
\hline$V 5(\%)$ & $0,3(0-4)$ & $0,1(0-1,3)$ & $53,8(6-92)$ & $\begin{array}{l}\text { 3DCRT- IMRT } \\
\text { 3DCRT - VMAT } \\
\text { forIMRT - VMAT }\end{array}$ & $\begin{array}{l}>0,05 \\
<\mathbf{0 , 0 0 1} \\
<\mathbf{0 , 0 0 1}\end{array}$ \\
\hline$V 10(\%)$ & 0 & 0 & $10,7(0-34,9)$ & $\begin{array}{l}\text { 3DCRT -VMAT } \\
\text { forIMRT -VMAT }\end{array}$ & $\begin{array}{l}<0,001 \\
<0,001\end{array}$ \\
\hline \multicolumn{6}{|c|}{ Heart parameters of left breast cancer patients } \\
\hline $\operatorname{Dmean}(G y)$ & $5,4(2,9-11,8)$ & $5,3(2,9-10,2)$ & $10,2(4,9-23,8)$ & $\begin{array}{l}\text { 3DCRT- IMRT } \\
\text { 3DCRT -VMAT } \\
\text { forIMRT- VMAT }\end{array}$ & $\begin{array}{l}>0,05 \\
<\mathbf{0 , 0 0 1} \\
<\mathbf{0 , 0 0 1}\end{array}$ \\
\hline $\operatorname{Dmax}(G y)$ & $49,6(47,5-51,9)$ & $49,2(47,6-52)$ & $44(18,1-54,8)$ & $\begin{array}{l}\text { 3DCRT- IMRT } \\
\text { 3DCRT - VMAT } \\
\text { forIMRT - VMAT }\end{array}$ & $\begin{array}{l}>0,05 \\
<\mathbf{0 , 0 1} \\
<\mathbf{0 , 0 5}\end{array}$ \\
\hline$V 5(\%)$ & $15,7(7-39,5)$ & $14,4(1,3-32,7)$ & $75(39,4-100)$ & $\begin{array}{l}\text { 3DCRT- IMRT } \\
\text { 3DCRT - VMAT } \\
\text { forIMRT - VMAT }\end{array}$ & $\begin{array}{l}>0,05 \\
<\mathbf{0 , 0 0 1} \\
<\mathbf{0 , 0 0 1}\end{array}$ \\
\hline$V 10(\%)$ & $10,8(3,7-29,4)$ & $10,6(3,7-26,5)$ & $35,3(4,2-98,9)$ & $\begin{array}{l}\text { 3DCRT- IMRT } \\
\text { 3DCRT -VMAT } \\
\text { forIMRT - VMAT }\end{array}$ & $\begin{array}{l}>0,05 \\
<\mathbf{0 , 0 0 1} \\
<\mathbf{0 , 0 0 1}\end{array}$ \\
\hline
\end{tabular}




\begin{tabular}{|c|c|c|c|c|c|}
\hline V35(\%) & $5,4(1-14,1)$ & $5,2(1-14,1)$ & $2(0-14)$ & $\begin{array}{l}\text { 3DCRT- IMRT } \\
\text { 3DCRT - VMAT } \\
\text { forIMRT -VMAT }\end{array}$ & $\begin{array}{l}>0,05 \\
<\mathbf{0 , 0 0 1} \\
<\mathbf{0 , 0 0 1}\end{array}$ \\
\hline
\end{tabular}

Data are presented as mean \pm standard deviation or median (minimum-maximum), where appropriate. Abbreviations: 3DCRT=Three-dimensional conformal radiotherapy; forIMRT=Forward planned intensity-modulated radiotherapy; VMAT $=$ Volumetric modulated arc therapy; Dmean=Mean dose; Dmin=Minimum dose; Dmax=Maximum dose
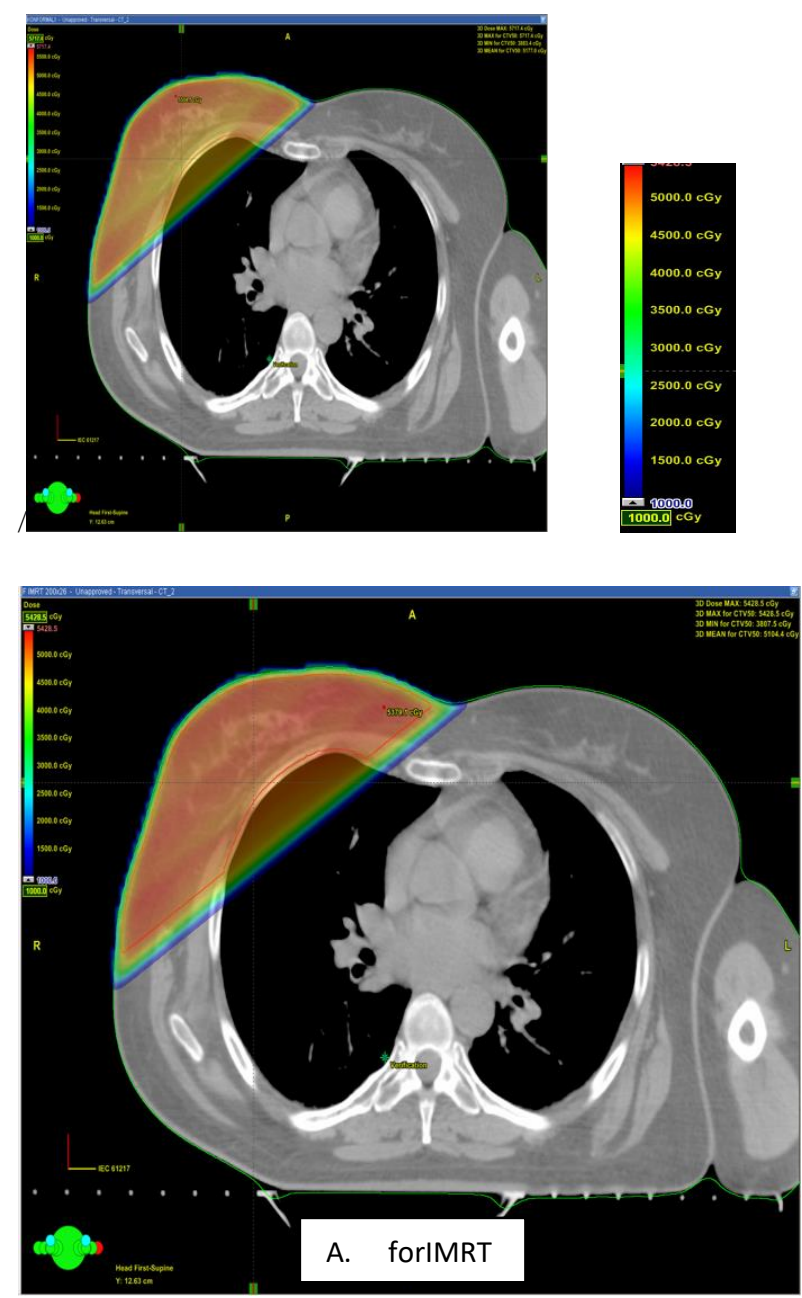

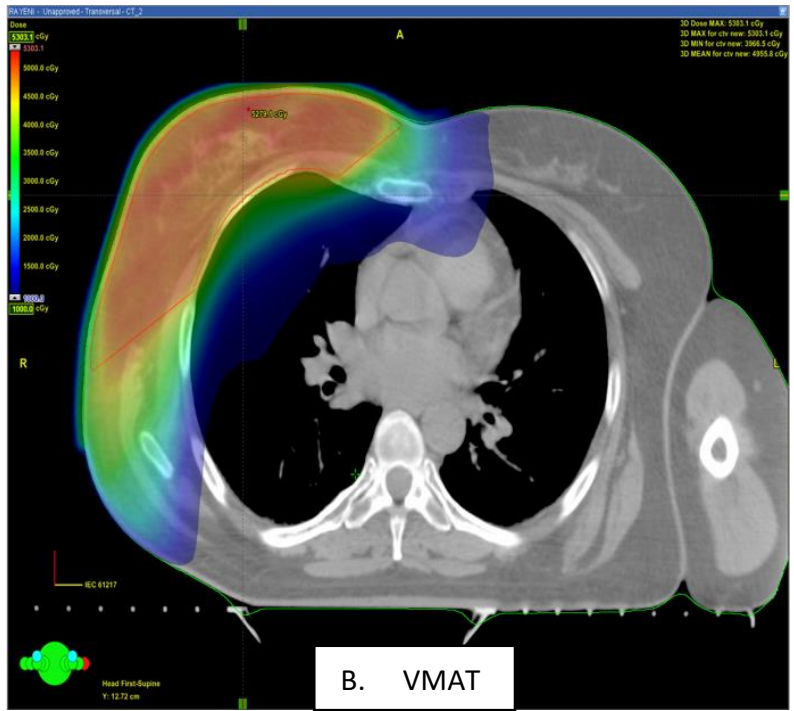

Figure 1. Dose distribution of a patient with right breast cancer

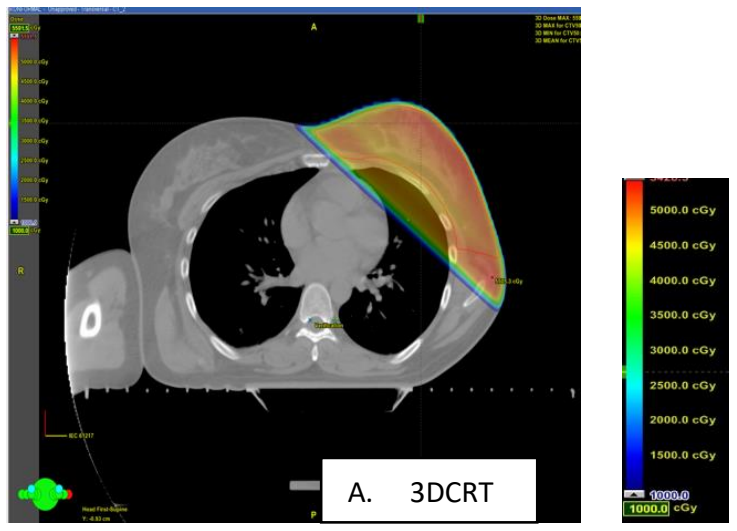



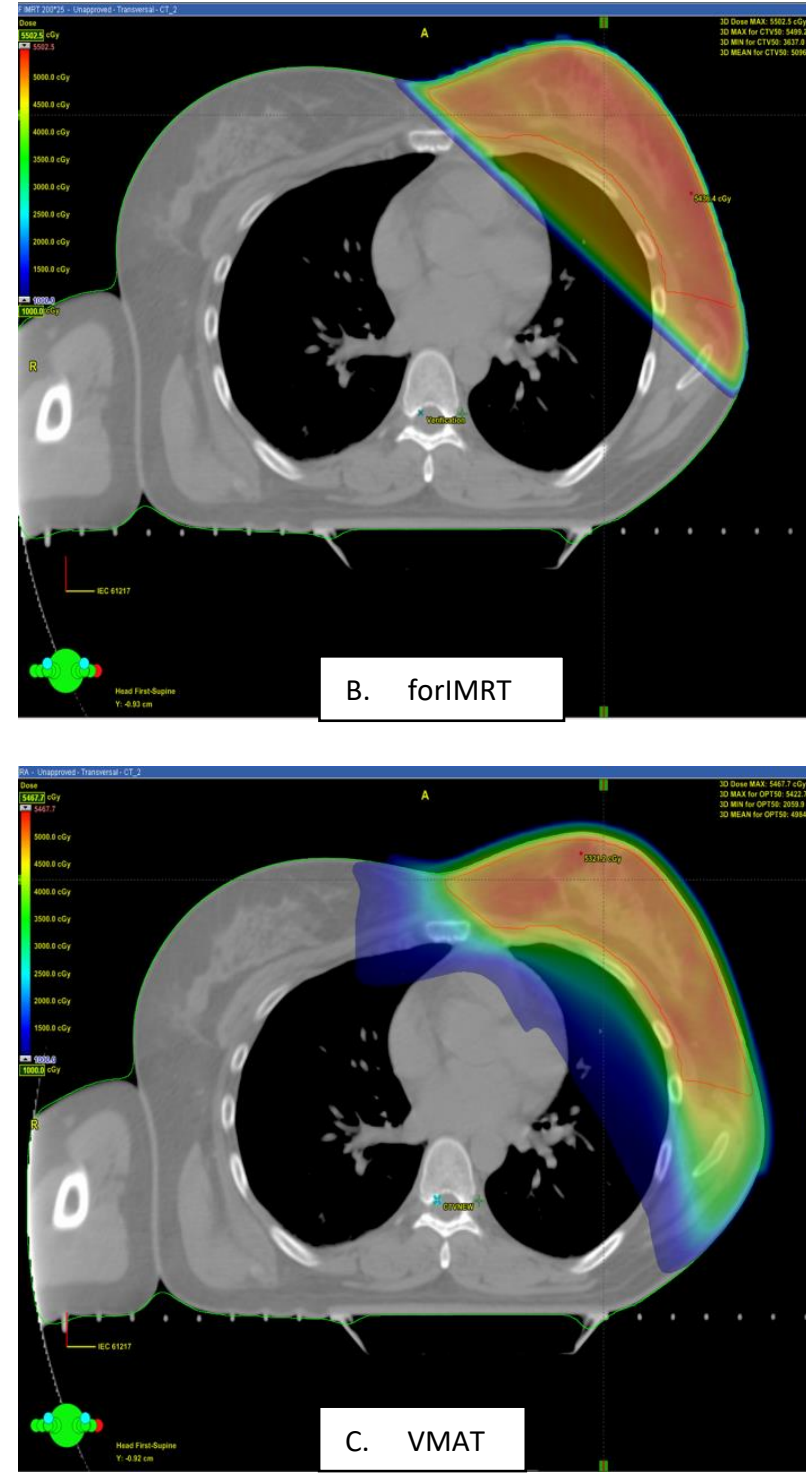

Figure2. Dose distribution of a patient with left breast cancer

Contralateral lung Dmean and Dmax were statistically significantly higher by VMAT compared to the other two methods. Similarly, while contralateral lung V5 was $0 \%$ for 3DCRT and forIMRT, the corresponding figure was calculated as $22 \%$ for VMAT.

Contralateral breast Dmean and Dmax values were higher by VMAT in comparison to the other two methods. While V5 was close to 0 for 3DCRT and forIMRT, it was $23.4 \%$ for VMAT. The lowest contralateral breast Dmax was achieved by forIMRT.
Heart parameters were separately calculated and compared in the patients with right and left breast cancer. In the planning of the 19 patients with left breast cancer, heart Dmean was found to be significantly higher for VMAT (10.2Gy) than that of the other two methods $(\mathrm{p}<0.001)$. However, heart Dmax was the lowest with VMAT (49.6Gy for 3DCRT, 49.2Gy for forIMRT, 44Gy for VMAT). Heart V5 and V10 values were found to be statistically significantly higher by VMAT compared to the other two methods. However, heart V35 was significantly lower by VMAT in comparison to the other two methods ( $2 \%$ for VMAT, $5.4 \%$ for 3DCRT, and $5.2 \%$ for forIMRT).

In comparison of the dose parameters of 16 patients diagnosed to have right breast cancer, there was an increase in heart Dmean and Dmax doses by VMAT $(\mathrm{p}<0.001)$. Heart V5 and V10 values were close to zero or zero for 3DCRT and forIMRT, whereas V5 value was $53.8 \%$ and V10 was $10.7 \%$ for VMAT. Although the forIMRT results concerning heart parameters of right and left breast cancer patients was better than that of 3DCRT, there was no significant difference between the methods.

\section{Discussion}

In this study, three current RT planning techniques in intact breast radiotherapy without regional lymph node irradiation were dosimetrically compared. Generally, the dosimetric studies have been concentrated on patients who receive nodal irradiation, and this present study is important as it is concentrated on localized disease group constituting the majority.

In the curative RT of intact breast, forIMRT has provided a superior alternative to 3DCRT, in which conventional wedge techniques are used $(5,14,15)$. The study of Herrick et al. (14) published in 2008 compared 3DCRT and forIMRT planning of 43 patients with breast cancer, in terms of hot spots in target breast volume. As a result, it was demonstrated that, compared to 3DCRT, $100 \%$ isodose curve was widened, $105 \%$ isodose curve was narrowed and $110 \%$ isodose curve could be eliminated by forIMRT plans. In our study, PTV $D_{\max }$ was calculated as 54Gy for 3DCRT, 52.9Gy for forIMRT and forIMRT provided statistically significant decreases in maximum doses ( $p<0.001)$. While the HI was $85.1 \%$ for forIMRT, it was $76.4 \%$ for 3DCRT, and 
forIMRT provided a decrease in hot spots in PTV and an increase in dose homogeneity in comparison to 3DCRT. Besides, our study compared 3DCRT and forIMRT techniques in terms of normal tissue doses. Although lower doses were achieved for ipsilateral lung, heart, contralateral lung and contralateral breast by forIMRT, they were not statistically significantly superior to that of 3DCRT. Only, contralateral breast $\mathrm{D}_{\max }$ dose was found to be statistically significantly lower by forIMRT.

In the study of McDonald et al. (2),240 patients were evaluated about the long-term outcomes of forIMRT and conventional RT (cRT) in breast cancer RT, it was reported that grade 2 and 3 acute skin reactions were significantly decreased by forIMRT ( $39 \%$ vs. $52 \%$ p=0.047). There was no significant difference between the two methods in terms of ipsilateral breast tumor recurrence, general survival, secondary primary of contralateral breast cancer, distant metastasis and secondary malignancy according to prior RT. Radiation pneumonitis developed in $1 \%$ of patients treated with forIMRT, and $2 \%$ of patients treated with cRT. While edema of the ipsilateral arm and fat necrosis was not observed in any of the patients receiving forIMRT, the rate of patients developing edema of the ipsilateral arm and fat necrosis in the cRT group were $4 \%$ and $2 \%$, respectively (2). According to these results, it can be said that forIMRT should be preferred in breast radiotherapy, where it is possible technically. Mihai et al. (6), in their study published in 2005 compared the results of 30 early stage breast cancer patients, who had undergone adjuvant whole breast RT after breast conserving surgery with forIMRT or inverse planned IMRT (invIMRT). Although a more homogeneous dose distribution was achieved by invIMRT, the difference between the two techniques was not statistically significant. It was stated that the $1.8 \%$ decrease in $\mathrm{D}_{110}$ by invIMRT, may not create a difference with regards to toxicity, therefore, from the clinical aspect, forward and inverse IMRT techniques may be considered to have equal effects.

The use of VMAT in breast RT is quite new. In the study of Popescu et al. (11) published in 2010; chest wall/breast, supraclavicular, axillar, internal mammary lymph node RT was replanned with VMAT and wide tangential 3DCRT techniques (MWT) in 5 patients with a diagnosis of left breast cancer, who had been previously treated with conventional IMRT (cIMRT: inverse-planned IMRT).The results of the three planning techniques were compared in terms of dosimetry and duration of treatment. Homogeneity index was calculated as $96 \%$ for VMAT, $94 \%$ for cIMRT and $84 \%$ for MWT. When heart, right and left lung, contralateral breast and healthy tissue doses were evaluated, VMAT dosimerty were observed to be better than cIMRT dosimetry. It was reported that VMAT provided a statistically significant decrease in intermediate-high and mean heart and ipsilateral lung doses $(p<0.05)$. In our study, similarly, the best HI was achieved by VMAT. However, our study demonstrated that heart V5, V10 and Dmean values were higher by VMAT in comparison to forIMRT in patients with right or left breast cancer who did not receive nodal irradiation including internal mammary lymph nodes. Only a decrease in heart V35 value was provided by VMAT.

The effect of breast RT on cardiac mortality and morbidity is an issue that has been studied since 1970. Paszat et al. (9) in a study performed in 1999 in 3006 patients, found that the risk of fatal myocardial infarction after RT was increased by $1-2 \%$ in left breast cancer patients compared to that in right breast cancer patients. Gyenes et al. (8) in a study performed in 960 patients indicated that high cardiac dose-volume was associated with ischemic heart disease. However, in 2005 Darby et al. (16) stated that the increase in heart disease risk has disappeared by the advances in RT after 1980s. Furthermore, in 2002, Vallis et al. (10) did not determine an increase in cardiac mortality or morbidity after 10.2 years follow-up in 2128 patients with left breast cancer treated with breast conserving surgery. When these studies are considered together, it can be said that the potential risk of cardiac morbidity and mortality in breast cancer patients has been decreased over the years by the advances in RT techniques. As for our study, VMAT decreased Dmax and V35 of heart, while increasing Dmean, V5 and V10 in patients diagnosed with left breast cancer in comparison to forIMRT and 3DCRT. However, VMAT led to a significant increase in heart doses of right breast cancer patients. As cardiac mortality is reported to be associated with high cardiac doses (8), it may be anticipated that VMAT would decrease the negative effects of RT on the heart. 
VMAT has been in clinical practice in breast RT nowadays. Scorsetti et al. (12) in a study published in August 2012, applied RT planned with VMAT and simultaneous integrated boost (SIB) in 50 early-stage breast cancer patients and reported early toxicity results. In that study, the dose scheme was 40.5 Gy delivered to the whole breast PTV and 48Gy to the boost PTV delivered in 15 fractions within 3 weeks. According to the results of skin toxicity and cosmetic scoring at the end of a median 12 months follow-up, it has been asserted that hypofractionated SIB with VMAT can be used with acceptable acute side effects in early-stage breast cancer.

Marks et al. (17) demonstrated that a $10 \%$ increase in the volume of heart receiving 30Gy dose in breast cancer patients who were treated with cIMRT caused a transient perfusion defect in the heart. Pignol et al. (18), in a randomized study, found that improved PTV homogeneity is associated with a decrease in the rate of skin wet desquamation. On the basis of these studies, it may be thought that VMAT may decrease the risk of cardiac perfusion defect by decreasing maximum heart dose and also may decrease the risk of wet desquamation by improving PTV homogeneity in comparison to forIMRT and 3DCRT. Similarly skin reactions will be less with forIMRT in comparison to 3DCRT.

Yorke et al. (19) have reported that the risk of radiation pneumonitis was $20 \%$ in cases V10 $\geq 50 \%$ and $\mathrm{V} 5>60 \%$ of the lung. In our study, ipsilateral lung V10 was $40.9 \%$ and V5 was $74.5 \%$ by VMAT. In that case, the risk of radiation pneumonitis may be increased by VMAT.

Stovall et al. (20) found that doses $\geq 1 \mathrm{~Gy}$ delivered to the contralateral breast during breast radiotherapy was associated with an increased risk of secondary primary breast cancer in females less than 40 years of age. No such relationship was found in women older than 40 years of age. In our study, contralateral breast Dmean was found to be $0.7 \mathrm{~Gy}$ for 3DCRT, 0.6Gy for forIMRT and 5.2Gy for VMAT. Clinical use of VMAT in women less than 40 years of age may increase the risk of secondary primary breast cancer in the contralateral breast. Late toxicity and secondary malignancy effects of VMAT should be evaluated in clinical studies with long-term follow-up.

\section{Conclusions}

Forward IMRT technique, that has been proven to be dosimetrically superior in intact breast RT without regional lymph node irradiation, should be preferred in place of 3DCRT, where possible. VMAT is successful in providing PTV homogeneity and in decreasing ipsilateral lung doses, and heart high doses in left breast cancer patients. However, it increases the low doses that the critical organs receive. In early-stage breast cancer patients with long survival, although the probability of late toxicity is decreased, secondary malignancy risk may be increased by VMAT. Clinical studies about treatment results of VMAT with long-term follow-up are required.

\section{Conflict of interest:None}

\section{REFERENCES}

1. Howlader N, Noone AM, Krapcho M, Garshell J, Neyman N, Altekruse SF, Kosary CL, Yu M, Ruhl J, Tatalovich Z, Cho H, Mariotto A, Lewis DR, Chen HS, Feuer EJ, Cronin KA (eds). SEER Cancer Statistics Review, 1975-2010, National Cancer Institute.

2. McDonald MW, Godette KD, Butker EK, Davis LW, Johnstone PA. Long-term outcomes of IMRT for breast cancer: a single-institution cohort analysis. Int J Radiat Oncol Biol Phys. 2008 Nov 15;72(4):103140.

3. Schubert LK, Gondi V, Sengbusch E, et al. Dosimetric comparison of left-sided whole breast irradiation with 3DCRT, forward-planned IMRT, inverse-planned IMRT, helical tomotherapy, and topotherapy. Radiother Oncol. 2011 Aug;100(2):2416

4. Fong A, Bromley R, Beat M, Vien D, Dineley J, Morgan G. Dosimetric comparison of intensity modulated radiotherapy techniques and standard wedged tangents for whole breast radiotherapy. J Med Imaging Radiat Oncol. 2009 Feb;53(1):92-9.

5. Herrick JS, Neill CJ, Rosser PF, et al. A comprehensive clinical 3-dimensional dosimetric analysis of forward planned IMRT and conventional wedge planned techniques for intact breast radiotherapy. Med Dosim. 2008 Spring;33(1): 6270

6. Mihai A, Rakovitch E, Sixel K, et al. Inverse vs. forward breast IMRT planning. Med. Dosim. 30: 149$54 ; 2005$.

7. Cardinale RM, Steele J, Fein DA, et al. The minimal dosimetric benefit of breast IMRT as compared to using a small number of forward planned MLC segments does not justify the cost (abstract 2629). Int J Radiat Oncol Biol Phys 2007; 69(3 Suppl):S553S554.

8. Gyenes G., Rutqvist LE., Liedberg A., et al. Longterm cardiac morbidity and mortality in a randomized trial of pre- and post-operative radiation therapy versus surgery alone in primary breast cancer. Radiother. Oncol. 1998;48:185-190. 
9. Paszat LF., Mackillop WJ., Groome PA., et al. Mortality from myocardial infarction following postlumpectomy radiotherapy for breast cancer: A population-based study in Ontario, Canada, Int. J. Radiat. Oncol. Biol. Phys. 1999;43:755-762.

10. Vallis KA., Pintilie M., Chong N., et al. Assessment of coronary heart disease morbidity and mortality after radiation therapy for early breast cancer. J. Clin. Oncol. 2002;20:1036-1042.

11. Popescu CC, Olivotto IA, Beckham WA, Ansbacher W, Zavgorodni S, Shaffer R, Wai ES, Otto K. Volumetric modulated arc therapy improves dosimetry and reduces treatment time compared to conventional intensity-modulated radiotherapy for locoregional radiotherapy of left-sided breast cancer and internal mammary nodes. Int J Radiat Oncol Biol Phys. 2010 Jan 1;76(1):287-95.

12. Scorsetti M, Alongi F, Fogliata A, Pentimalli S, Navarria P, et al. Phase I-II study of hypofractionated simultaneous integrated boost using volumetric modulated arc therapy for adjuvant radiation therapy in breast cancer patients: a report of feasibility and early toxicity results in the first 50 treatments. Radiat Oncol. 2012 Aug 28;7(1):145.

13. Nicolini G, Fogliata A, ClivioA, et al. Planning strategies in volumetric modulated arc therapy for breast. Med. Phys. 38, 4025 (2011)

14. Ninet de la Torre, Carmen $\mathrm{T}$ Figueroa, Krystal Martinez, et al. A comparative study of surface dose and dose distribution for intact breast following irradiation with field-in-field technique vs. the use of conventional wedges. Med. Dosim. 29:109-14;2004

15. Kestin, L.L.; Sharpe, M.B.; Frazier, R.C.; et al. Intensity modulation to improve dose uniformity with tangential breast radiotherapy: Initial clinical experience. Int. J. Radiat. Oncol. Biol. Phys. 48:155968;2000.

16. Darby SC., McGale P., Taylor CW., et al. Long-term mortality from heart disease and lung cancer after radiotherapy for early breast cancer: Prospective cohort study of about 300,000 women in US SEER cancer registries. Lancet Oncol. 2005;6:557-565

17. Marks LB, Yu X, Prosnitz RG, et al. The incidence and functional consequences of RT-associated cardiac perfusion defects. Int $\mathrm{J}$ Radiat Oncol Biol Phys 2005;63:214-223.

18. Pignol JP, Olivotto I, Rakovitch E, et al. A multicenter randomized trial of breast intensitymodulated radiation therapy to reduce acute radiation dermatitis. J Clin Oncol 2008;26:2085-2092.

19. Yorke ED, Jackson A, Rosenzweig KE, et al. Correlation of dosimetric factors and radiation pneumonitis for non-small cell lung cancer patients in a recently completed dose escalation study. Int $\mathbf{J}$ Radiat Oncol Biol Phys 2005;63:672-682.

20. Stovall M, Smith SA, Langholz BM, et al. Dose to the contralateral breast from radiotherapy and risk of second primary breast cancer in the WECARE study. Int J Radiat Oncol Biol. Phys 2008;72:10211030. 